\title{
Snow Crab (Chionoecetes opilio) Distribution Limits and Abundance Trends on the Scotian Shelf
}

\author{
M. J. Tremblay \\ Invertebrate Fisheries Division, Science Branch \\ Department of Fisheries and Oceans, P. O. Box 550 \\ Halifax, Nova Scotia, Canada
}

\begin{abstract}
The distribution and abundance of snow crab (Chionoecetes opilio) near its southern limit of the Scotian Shelf is characterized from commercial fishing locations and from groundfish trawl surveys. Groundfish surveys also provide data on bottom temperature. Snow crab are most abundant on the eastern Scotian Shelf where bottom temperature is generally $<3^{\circ} \mathrm{C}$ even in summer; they are absent from the deep central Shelf, "Scotian Gulf", which has access to warmer offshore waters. West of the Scotian Gulf snow crab abundance is low, likely ephemeral, and limited to pockets of cold bottom water. The fishery exploits most of the areas where snow crab are expected to be abundant on the Scotian Shelf. Mean annual catch rate by trawls was correlated with mean annual commercial catch rate for the 1980-94 period. There is some evidence of an endogenous cycle in recruitment, but other factors such as changes in bottom temperature appear important to snow crab production on the eastern Scotian Shelf. It cannot be resolved whether the high biomass at the beginning of the fishery resulted from a peak in a recruitment cycle, or from the accumulation of biomass of the virgin population. Year-classes that originated in the mid-1970s and those that entered the fishery from 1982-86 were small; those that supported high landings in the late-1980s and early-1990s may have been larger because of increased survival of early life-history stages, but the reasons for any increased survival are not clear. Lower temperatures after 1984 appear to have contributed to expanded habitat, and reduced predation from groundfish may have increased the survival and growth of juvenile and adolescent snow crab on the eastern Scotian Shelf.
\end{abstract}

Key words: abundance, distribution, recruitment, Scotian Shelf, snow crab, temperature

\section{Introduction}

Snow crab (Chionoecetes opilio) is a subarctic species that occurs in the Atlantic from northern Labrador to the Gulf of Maine (Rathbun, 1929, Powles, 1968). Adults occur primarily on mud bottoms with year-round temperatures of 0 to $5^{\circ} \mathrm{C}$ (Elner, 1982a). In the southern Gulf of St. Lawrence, they are most common at temperatures of -1 to $2^{\circ} \mathrm{C}$, but can occur at bottom temperatures as high as $10^{\circ} \mathrm{C}$ (Powles, 1968).

In Atlantic Canada the combination of mud substrate and low temperature occurs over a broad depth range-commercial fishing occurs from about 45-380 $\mathrm{m}$ in Atlantic Canada (Dufour, 1988). Juveniles and females are often separate from and more highly aggregated than large males (Miller, 1975; Brêthes et al., 1987; Robichaud et al., 1989). Short distance seasonal migrations for molting and mating occur in some areas (Hooper, 1986; Ennis et al., 1990; Sainte-Marie and Hazel, 1992), but mark-recapture studies of large males indicate annual movements of less than $25 \mathrm{~km}$ (Dufour, 1988; Lefebvre and Brêthes, 1991).
As in other benthic invertebrates with planktonic larvae, the extent of larval dispersal must affect the distribution of snow crab. The fecundity averages between 50000 and 80000 eggs (Davidson et al., 1985; Taylor, 1988). The larvae that hatch from these eggs may be planktonic for 4 months or more (Lanteinge, MS 1985; Elner, 1988; Lovrich et al., 1995), and depending upon the prevailing residual currents and on larval behaviour, larvae may be displaced some distance from their place of origin. Counts of larvae in neuston samples from the Scotian Shelf in 1977-78 indicated that early stages were most abundant in the northeast, while later stages were found almost exclusively in the southwest (Roff et al., 1986). The authors suggested that snow crab larvae drift with the residual current.

Major commercial stocks of snow crab exist in the Gulf of St. Lawrence, and off the east coast of Newfoundland. A smaller and more variable commercial fishery also exists off eastern Cape Breton (Fig. 1), near the species southern distribution limit. The long-term annual mean landings for eastern Cape Breton (852 tons) have 


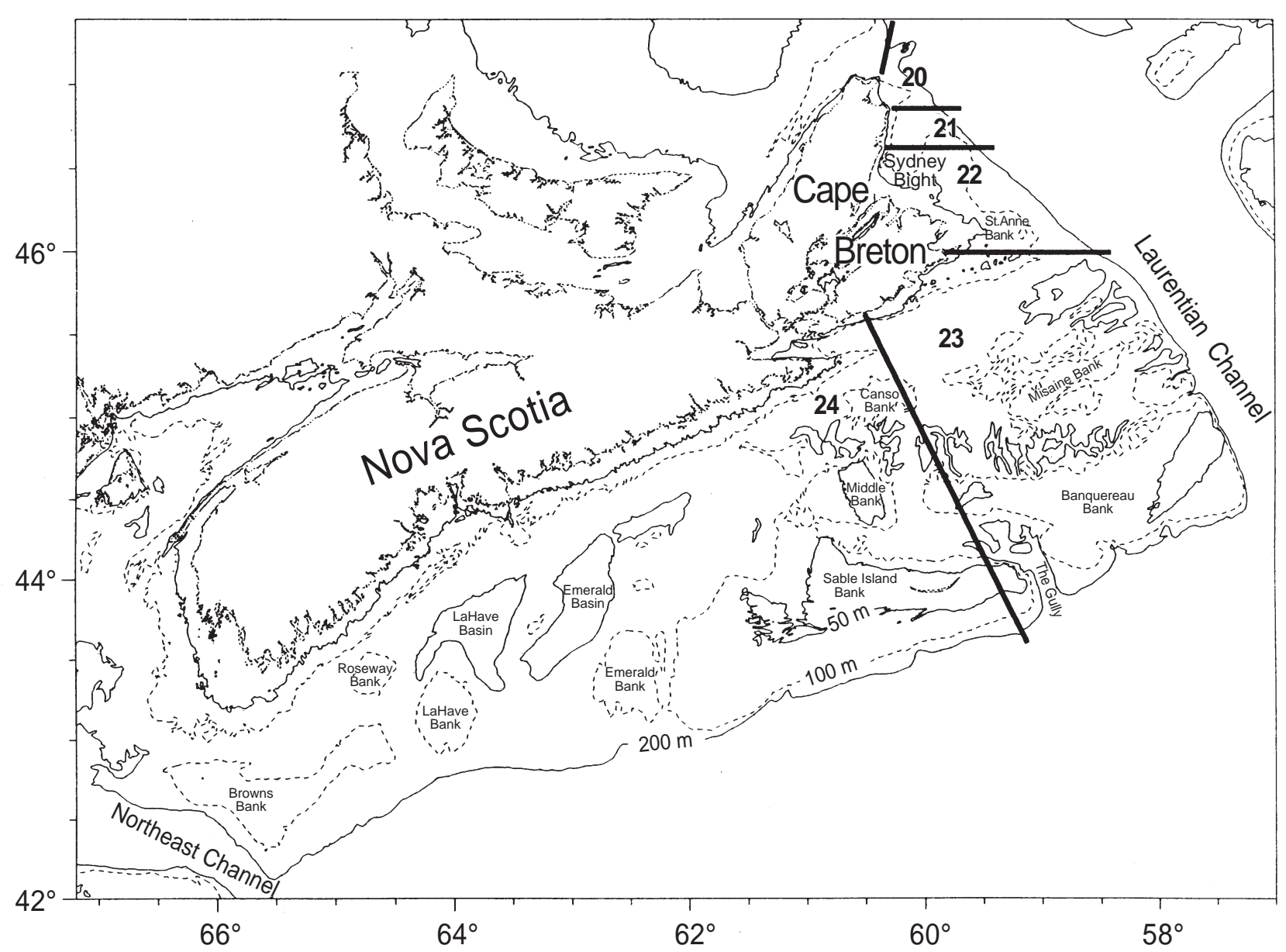

Fig. 1. Map of the Scotian Shelf, with major topographic features, and Snow Crab Fishing Areas.

been less than one tenth that of the southern Gulf of St. Lawrence, or Newfoundland (Fig. 2). Landings off eastern Cape Breton have also been more variable (coefficient of variation $(\mathrm{CV})=76 \%$ ) than the other two areas ( $C V=37$ and $46 \%$ ) but this may be due partly to quota management in the Gulf of St. Lawrence and Newfoundland. Landings rose rapidly after snow crab fishing began off eastern Cape Breton in the late-1970s, but soon declined (Fig. 2). Just when the annual commercial catch was at a historical low (1985), a pulse of prerecruits appeared off eastern Cape Breton, and landings and catch rates rose steadily from 1988 to 1993 (Tremblay et al., 1994). Analyses of catch rate, spatial distribution of effort, biomass and population structure indicate that the increased landings resulted from 3 factors: (i) increased abundance and biomass, (ii) expanded fishing area, and (iii) increased total effort (Tremblay et al., 1994). Even with the recent expansion in fishing grounds, most fishing effort for snow crab on the Scotian Shelf has occurred east of $61^{\circ} 30^{\prime} \mathrm{W}$ (Fig. 1).

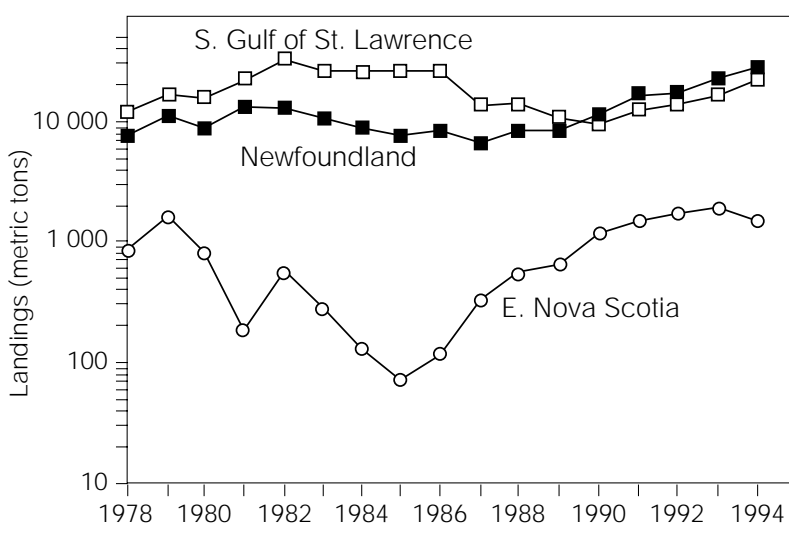

Fig. 2. Snow crab landings from the southern Gulf of St. Lawrence (Snow Crab Areas 12, 18, 19, 25 and 26), for the Newfoundland Region and for Eastern Cape Breton (Snow Crab Areas 20 to 24). Data sources: DFO Statistics Branch, Moncton (Southern Gulf); DFO Statistics Branch, St. John's (Newfoundland Region); Tremblay et al., 1994 and DFO Statistics Branch, Halifax (Eastern Cape Breton). 
The early collapse of snow crab stocks off eastern Cape Breton suggested that growth and recruitment were low due to marginal habitat (EIner, 1982b). As such, it was hypothesized that prior to exploitation, the stocks were built up over time via trickles of movement, growth and recruitment. The consistently high catch rates since 1988, and the expanded fishing grounds suggest that the snow crab grounds off eastern Cape Breton are more productive than first thought (Elner et al., MS 1990).

Little effort has been directed at determining the limits to snow crab distribution on the Scotian Shelf. Limits may be imposed by hydrography or bottom type. The extent of snow crab distribution on the Shelf is of particular interest because of increased fishing effort in recent years (Tremblay et al., 1994), and interest in fishing beyond the current fishing grounds. The objectives of this paper are to describe the distribution of snow crab on the Scotian Shelf in relation to the physical environment, and to evaluate possible causes of the changes in snow crab production.

\section{Physical setting}

The bathymetry of the Scotian Shelf is complex, with a series of outer banks and two deep central basins (Fig. 1). La Have and Emerald Basins, with access to the slope, are sometimes referred to as the Scotian Gulf. The waters of the Scotian Shelf are derived from the Gulf of St. Lawrence, the Labrador Current, and North Atlantic water (Smith et al., 1978). The confluence of these waters results in what can be viewed as a 3-layered system on the Scotian Shelf: (i) an upper layer with seasonally varying temperatures and salinity $<32 \%$, (ii) a cold intermediate layer with temperatures $<5^{\circ} \mathrm{C}$ and salinities $>32.5 \%$, and (iii) a warm bottom layer with temperatures $>5^{\circ} \mathrm{C}$ and salinities $>33.5 \%$ ( Hachey, 1942; McLellan, 1954a; Smith et al., 1978).

The mean current on the Scotian Shelf is to the southwest, and waters that flood the Scotian Shelf from the northeast are progressively modified by warmer, higher salinity slope water (McLellan, 1954a; Houghton et al., 1978). As such, bottom water temperatures on the Scotian Shelf are a function of both depth and location, with the coldest bottom temperatures in the northeast, and the warmest in the deep central basins (McLellan, 1954b).

Recent papers provide more details of temperature distribution and water circulation. Analysis of a historical temperature database (Loder et al., 1997) indicates that mean bottom temperatures during summer are between 0 and $3^{\circ} \mathrm{C}$ on the eastern Scotian Shelf and in a narrow band along the east coast of Nova Scotia (Fig. 3). In the Scotian Gulf mean temperatures are $6-9^{\circ} \mathrm{C}$, while just to the west, between La Have Basin and Browns Bank, mean temperatures are $3-6^{\circ} \mathrm{C}$. Analysis of circulation associated with density gradients and topography indicate that although there is alongshelf flow on the Scotian Shelf, there is a tendency for clockwise gyres over banks, and counterclockwise gyres over basins (Loder et al., 1997; Sheng and Thompson, 1996). As such, the hydrographic regime of the eastern Scotian Shelf is to some extent autonomous from that of adjacent areas (southern Newfoundland Shelf and western Scotian Shelf).

The surficial geology of the Scotian Shelf is closely related to bottom depth. Offshore banks and the inner shelf $(<100 \mathrm{~m})$ are characterized by Sable Island Sand and Gravel, a formation ranging from well sorted sands to pebbles, cobbles and boulders (Fader, 1991). Bedrock is frequently exposed on the shallow inner shelf. Adjacent to the banks is a siltclay sand (Sambro Sand). The deep central basins and troughs of the eastern Scotian Shelf are areas of active mud deposition (Piper, 1991), and are covered by a formation known as LaHave Clay (Fader, 1991). Adjacent to the basins are areas of Scotian Shelf Drift, a glacial till ranging up to boulder size, and Emerald Silt.

\section{Materials and Methods}

\section{Commercial fishing logs}

Data on the distribution of snow crab on the Scotian Shelf were available from commercial fishing logs and groundfish trawl surveys. The bottom temperature and depth during groundfish surveys was used to characterize the physical environment. These data sources, and their treatment in this paper, are described below.

All snow crab fisheries are prosecuted with baited traps and females are not retained because of their small size, and to maximize reproductive potential. Off eastern Cape Breton fishers are limited to 30 traps during a 9-week season (late-July until September). Traps are constructed of wood or steel and can be rectangular, conical or pyramidal in shape. Commercial fishing logs of snow crab catch, number of trap hauls, and location have been used to estimate annual landings, catch rate and effort by snow crab area since 1978 (Tremblay et al., 1994). The mean annual catch rates used here are for Areas 20-24 (grouped) as in Tremblay and Eagles (MS 1995). Additional data on fishing location were available from the fishing logs of a small experimental fishery on the western Scotian Shelf which was active in 1994-95. 


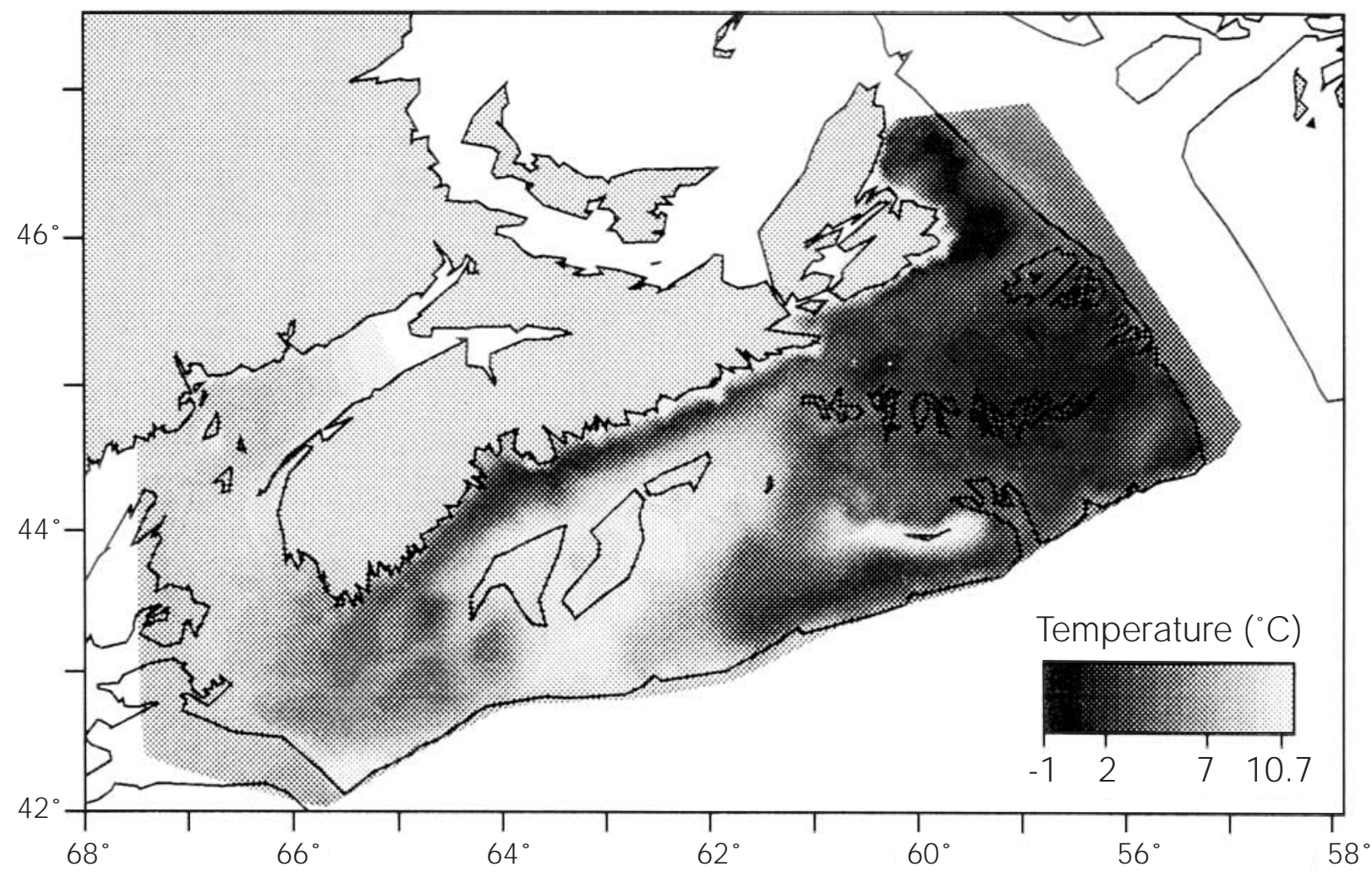

Fig. 3. Shaded contours of mean bottom temperature in summer, interpolated from a historical database covering 1970-94. Temperature data obtained from Dr J. Loder (Bedford Institute of Oceanography), and described in Loder et al., 1997.

To illustrate the location and success of fishing effort, the log data were first grouped into the periods 1978-84, 1985-89 and 1990-95. For each period the average catch rate (kg per trap haul) was calculated for grid squares of approximately 121 $\mathrm{km}^{2}$ ( $5^{\circ}$ latitude by $10^{\circ}$ longitude).

\section{Groundfish trawl surveys}

Groundfish trawl surveys have been conducted at least once per year on the Scotian Shelf since the 1950s (Halliday and Koeller, 1981), but snow crab were not enumerated until 1980 . The shelf was surveyed several times per year from 1980 to 1994 using a stratified-random design. Only those surveys which were part of a regular series were accessed (Table 1). Survey samples ("sets") consisted of towing a Yankee 36 trawl (summer surveys of 1980 and 1981) or a Western Ila trawl (all other surveys) at 3.5 knots for approximately 30 minutes in the direction towards the next random station. The wing spread of Western Ila trawls ranges from approximately $8-20 \mathrm{~m}$, depending on factors such as depth of the tow (Koeller, 1991). The mesh size in groundfish trawls is largest in the wings and smallest in the codends. In terms of extended measure, mesh length is $130 \mathrm{~mm}$ in the wings, and as small as $6 \mathrm{~mm}$ in the Yankee 36 codend liner, and $19 \mathrm{~mm}$ in the Western Ila codend liner (Carrothers, 1988).

For each set, snow crab were enumerated and the total number standardized to a $3.24 \mathrm{~km}$ $(1.75 \mathrm{~nm})$ tow length. Sex and carapace width were not recorded during regular groundfish surveys. These data were available in 1994 from a special trawl survey directed at seal worm in groundfish in the Sable Island area. In 1993 snow crab were caught frequently (J. Martell, DFO Science, Maritimes Region, pers. comm.), and during the May 1994 study, the number of snow crab was determined for all sets, and snow crab carapace width was measured for some sets. Gear type and methods were as in regular groundfish surveys.

Bottom temperature and depth were measured for most groundfish sets. To evaluate the null hypotheses that snow crab were distributed randomly with temperature and depth, chi-square tests were used. Expected numbers within temperature and depth categories were based on the assumption that snow crab occurrence would 
TABLE 1. Groundfish trawl surveys used to delineate distribution of snow crab. Date ranges are earliest and latest dates over all years.

\begin{tabular}{|c|c|c|c|c|}
\hline Date Ranges & Years & Series & Area & Number of Sets \\
\hline $13 \mathrm{Feb}-14 \mathrm{Apr}$ & $1980-84$ & Spring & Scotian Shelf & 674 \\
\hline $27 \mathrm{Feb}-01 \mathrm{Apr}$ & $1986-94$ & 4VW Cod & E. Scotian Shelf & 736 \\
\hline $13 \mathrm{Feb}-18 \mathrm{Mar}$ & $1986-94$ & Georges & Georges Bank & 852 \\
\hline 23 Jun-06 Aug & $1980-94$ & Summer & Scotian Shelf & 2596 \\
\hline \multirow[t]{2}{*}{28 Sep-27 Nov } & $1980-84$ & Autumn & Scotian Shelf & 945 \\
\hline & & & Total & 5803 \\
\hline
\end{tabular}

be proportional to sampling effort. Adjacent categories were combined so that the expected number per category was $>3$ (Ostle and Mensing, 1975).

The temperature regime in summer from 1980 to 1994 was characterized with the annual mean stratified temperature from summer groundfish surveys. The mean was estimated for two areas: (i) the whole survey area, and (ii) the eastern Scotian Shelf and Sydney Bight (west of approximately $62^{\circ} \mathrm{W}$, groundfish strata $\left.440-459\right)$.

\section{Results}

\section{Fishing effort}

Fishing locations and catch rates off eastern Cape Breton are summarized for the three periods in Fig. 4. Between 1978 and 1984 effort was largely restricted to within about $40 \mathrm{~km}$ of shore and catch rates averaged about 15-30 kg per trap haul (Fig. 4a). From 1985 to 1989 the average catch rates were similar to the earlier period, but snow crab were trapped further to the southeast (Fig. 4b). From 1990 to 1995 catch rates were high particularly in Areas 23 and 24, and snow crab were trapped up to $150 \mathrm{~km}$ from shore off southeastern Cape Breton (Fig. 4c).

The experimental fishing on the western Scotian Shelf consisted of approximately 12470 trap hauls from July 1994 though September 1995. Catches were mainly in the area just north of the eastern portion of Browns Bank (Fig. 4c). The average weekly catch rate of $1.5 \mathrm{~kg} / \mathrm{trap}$ haul was low compared to that in Areas 20-24.

\section{Groundfish surveys}

The groundfish surveys covered a much larger area than the commercial fishery, but the incidence of snow crab in the trawl catch was low (Fig. 5 and $6)$. Of a total of 5803 trawl sets between 1980 and 1994, 96 (1.7\%) yielded snow crab (Tables 1 and $2)$. For examination of possible day-night differences in trawl catch, only the summer series was used because the number of snow crab caught during other series was too low. Frequency of occurrence was not related to time of day since positive sets were proportional to the number of sets during day, night and twilight (Table 3). There was also no significant effect of time of day on the number of snow crab caught per trawl (Table 3), but the small sample size precluded a powerful test. To ensure the results were not confounded with any effect of different trawl types (Yankee 36 versus Western Ila), the analysis was rerun without the 1980-81 data (when the Yankee 36 was used); the results were unchanged.

Annual trends in the frequency and number of snow crab collected in summer trawl sets were similar to trends in the commercial fishery. Between 1990 and 1994, when catch rates in the commercial fishery were near record highs for several areas, and fishing covered the largest area (Fig. 4), the summer groundfish surveys collected snow crab in greater numbers over a wider area than during previous years (Fig. 6). A one-way analysis of variance indicated that the number of snow crab per stratified tow was greater from 1990-94 than from 1980-84 and 1985-89 (Table 4). To ensure trawl type was not a factor, the analysis of variance was rerun without the 1980-81 data; there was still a significant difference among periods. The mean annual catch rate by traps was significantly correlated with the mean number per tow from groundfish surveys (Fig. 7), although the correlation was low $(r=0.51, p=0.05, n=15)$.

During each season most snow crab were collected on the eastern Scotian Shelf and in the Sydney Bight area (Fig. 5 and 6). There were only 3 positive sets west of $62^{\circ} \mathrm{W}$ and no snow crab were captured during surveys of Georges Bank. Most were caught during the summer surveys, but this was a reflection of more sets.

There were no records of commercial fishing 10-30 km north of Sable Island (Fig. 4), but snow 


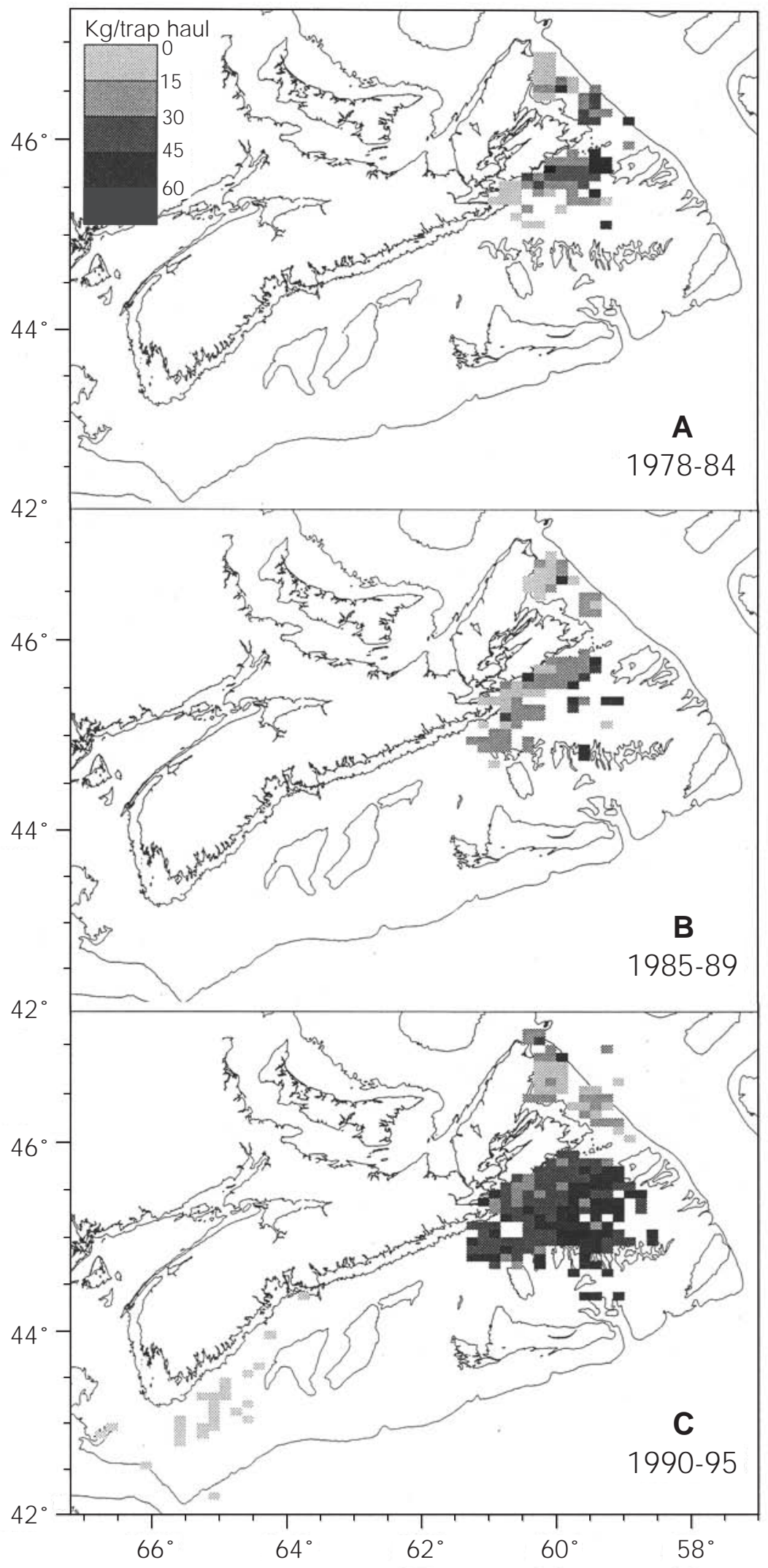

Fig. 4. Average annual catch rate in commercial snow crab fishery, for (A) 1978-84, (B) 1985-89; and (C) 1990-95. Data are from fishing logs, and are depicted by 5 by 7 mile squares. 

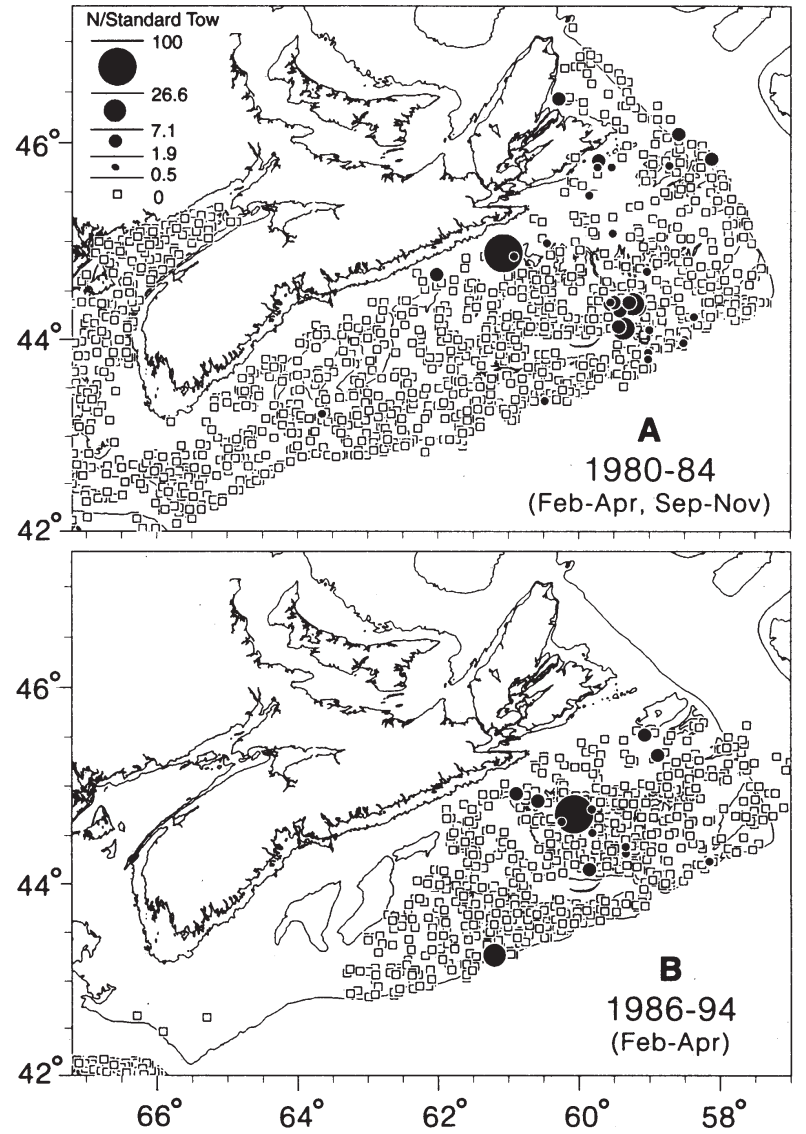

Fig. 5. Numbers of snow crab per set during (A) Spring and autumn groundfish surveys 1980-84, and (B) Georges Bank and 4VW cod surveys 1986-94. See Tables 1 and 2 for survey details.

crab were frequently caught there during the summer groundfish surveys (Fig. 6). The single largest trawl catch was from this area in July $1993(n=91)$. The May 1994 trawl survey directed at sealworm provided higher resolution distribution data. Snow crab were common north of Sable Island, but not to the south (Fig. 8). The bottom type at all locations sampled in Fig. 8 was a combination of sand, gravel, and shells (J. Martell, DFO, Maritimes Region, pers. comm.). Carapace width ranged from 37-92 mm (Fig. 9), with a mean of $56 \mathrm{~mm}$ for females, and 64 $\mathrm{mm}$ for males.

Snow crab were not randomly distributed with temperature for any of the surveys based on chisquare tests (Table 5). When all the groundfish surveys from 1980 to 1994 were grouped, snow crab were distributed predominantly in areas where bottom temperature was less than $7^{\circ} \mathrm{C}$ (Fig. 10). Over $25 \%$ of the positive sets were from areas where bottom temperatures were $1-2^{\circ} \mathrm{C}$. Snow crab were not distributed randomly with depth either (Table 6), with positive sets tending to be at greater depths (Fig. 11).
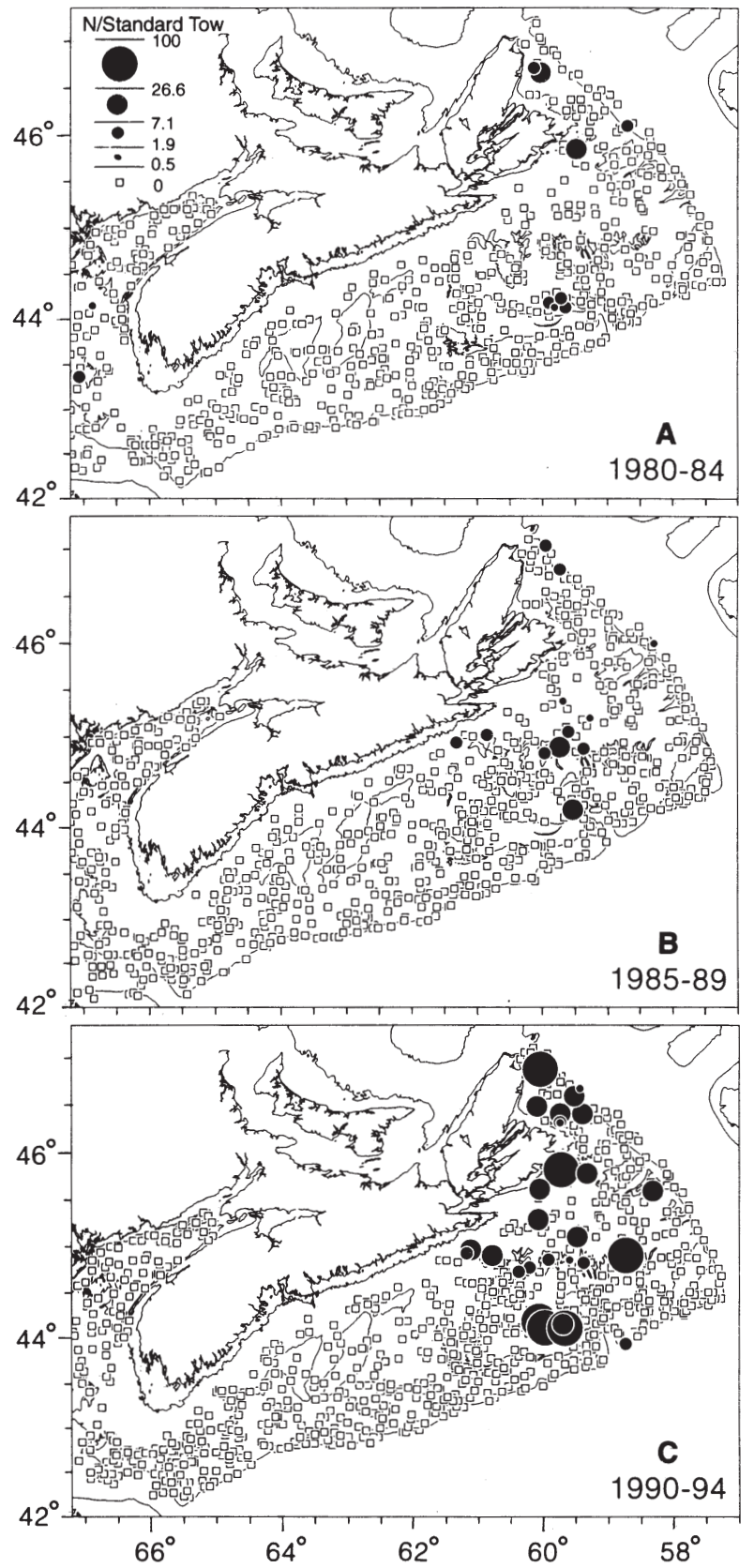

Fig. 6. Numbers of snow crab per set during summer groundfish surveys. (A) 1980-84; (B) 1985-89; (C) 1990-94.

From 1984 to 1991 the mean stratified temperature on the Scotian Shelf during summer trended downward (Fig. 12). Temperatures in 1993 and 1994 increased, but were still lower than 1984-85.

\section{Discussion}

Data on snow crab distribution from fishing locations and groundfish surveys indicate a marked 
TABLE 2. Incidence of snow crab in groundfish surveys. $N$ is mean of annual stratified means.

\begin{tabular}{lrcc}
\hline \hline Series & $\begin{array}{c}\text { Number of sets with } \\
\text { snow crab (\%) }\end{array}$ & N per set & $\begin{array}{c}\text { Maximum number } \\
\text { per set }\end{array}$ \\
\hline Spring & $4(0.6)$ & 0.016 & 2.1 \\
4VWCod & $14(1.9)$ & 0.062 & -9 \\
Georges & $0(0.0)$ & - & - \\
Summer 1980-84 & $12(1.6)$ & 0.085 & 20.6 \\
Summer 1985-89 & $12(1.4)$ & 0.064 & 12.4 \\
Summer 1990-94 & $29(2.9)$ & 0.625 & 91.4 \\
Autumn & $25(1.5)$ & 0.123 & 30.9 \\
Total & $96(1.7)$ & & \\
\hline
\end{tabular}

TABLE 3. Effect of time of day on snow crab incidence and abundance in summer trawl surveys. Number of sets is less than Table 2 because of incomplete data on time of sampling. Data were transformed to natural logarithms Ln $(x+1)$ before conducting ANOVA because of unequal variances in the raw data.

SUMMARY (untransformed data)

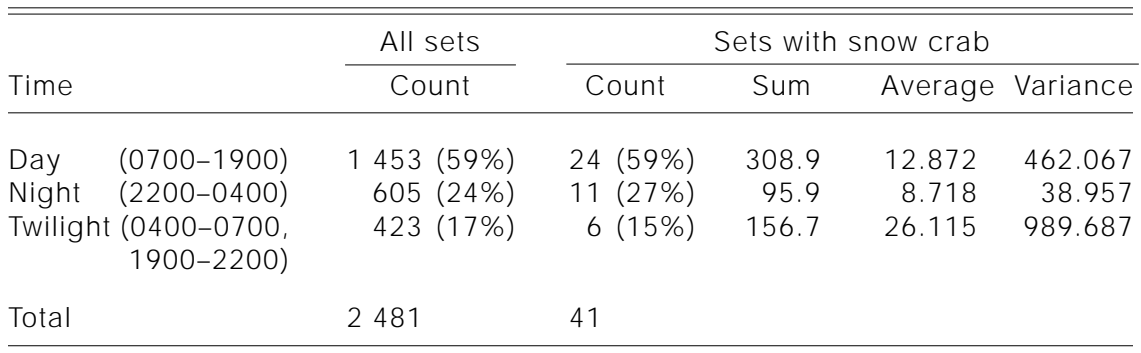

ANOVA: Number per stratified set on time of day (log transformed data)

\begin{tabular}{lccccc}
\hline $\begin{array}{l}\text { Source of } \\
\text { Variation }\end{array}$ & Sum Squares & df & $\begin{array}{c}\text { Mean } \\
\text { Square }\end{array}$ & $F$ & P-value \\
\hline Between Groups & 3.420 & 2 & 1.710 & 0.990 & 0.38 \\
Within Groups & 65.666 & 38 & 1.728 & & \\
Total & 69.08740 & & & & \\
\hline
\end{tabular}

decline in abundance from east to west on the Scotian Shelf. Although the incidence of snow crab was low in the groundfish surveys, the surveys provide the only data on distribution that is independent of the fishery. Tremblay et al. (1994) interpreted the increased commercial landings in the 1990s to be at least partly due to increased abundance. The significantly greater catch rates for the 1990-94 period, and the significant correlations (albeit weak) between annual mean catch rates of snow crab by trawls and that by commercial traps supports this interpretation.
The low frequency and catch rates of snow crab in groundfish trawls suggest that they were undersampled, but evaluation is difficult because there are no absolute density estimates of snow crab for the Scotian Shelf. Beam trawls can underestimate density by a factor of 4 or 5 due to active avoidance or the crabs partially burying themselves in the mud (Miller, 1975). The catch composition of trawls differs from traps not only in size, but in shell condition and maturity. Comparison of the snow crab catch by a Western Ila bottom trawl with that of different trap types indicated that traps 
TABLE 4. Number of snow crab collected during stratified tows over 5-year periods from 1980-94. Data were transformed to natural logarithms $\operatorname{Ln}(x+1)$ before conducting ANOVA because of unequal variances in the raw data.

SUMMARY (untransformed data)

\begin{tabular}{lcccr}
\hline \hline & & \multicolumn{2}{c}{ Number of snow crab per stratified set } \\
\cline { 3 - 5 } Period & Number of sets & Total & Average & Variance \\
\hline Summer 1980-84 & 734 & 61.3 & 0.084 & 0.984 \\
Summer 1985-89 & 872 & 54.0 & 0.062 & 0.476 \\
Summer 1990-94 & 990 & 533.4 & 0.539 & 24.942 \\
\hline
\end{tabular}

ANOVA: Number per stratified set on period (log transformed data)

\begin{tabular}{lrrrrrr}
\hline $\begin{array}{l}\text { Source of } \\
\text { Variation }\end{array}$ & Sum Squares & df & $\begin{array}{c}\text { Mean } \\
\text { Square }\end{array}$ & F & P-value & F crit \\
\hline $\begin{array}{l}\text { Between Groups } \\
\text { Within Groups }\end{array}$ & 1.384 & 2 & 0.692 & 6.941 & 0.001 & 2.999 \\
Total & 258.408 & 2593 & 0.010 & & & \\
\hline
\end{tabular}

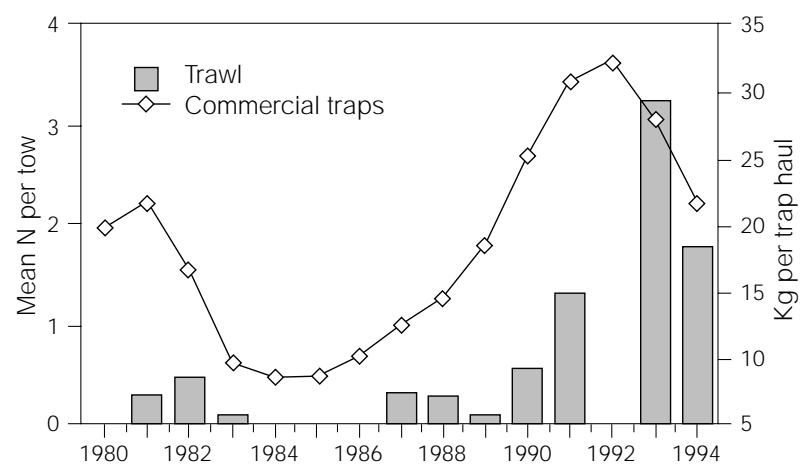

Fig. 7. Snow crab catch rate by commercial fishery and during groundfish surveys. Commercial catch rate (kg snow crab per trap haul) is mean for Snow Crab Fishing Areas 20-24 from Tremblay et al., (1994). Trawl catch rate is annual stratified mean of number of snow crab per set in summer groundfish surveys. Only survey stations on the eastern Scotian Shelf and Sydney Bight are included (east of approximately $61^{\circ} 30^{\prime}$, strata numbers 440-459).

were selective for hard and large-claw crab (Hoenig and Dawe, MS 1991).

The lack of an effect of time of day on snow crab catch rate in groundfish trawls differs from other findings and may be a result of low sample size. Stehlik et al. (1991) reported higher catches at night for 4 species of crabs, including jonah crab (Cancer borealis) that occurred at depths comparable to snow crab on the Scotian Shelf. Hoenig and Dawe (MS 1991) reported a day-night difference in catch composition of a Western IIA trawl.

Bottom temperature on the Scotian Shelf appears to be a prime determinant for snow crab distribution. The area of major commercial fishing effort corresponded closely to the area where mean bottom water temperatures in summer were less than $3^{\circ} \mathrm{C}$, and snow crab were found most frequently in cold waters in trawl surveys. Although there were no direct measurements of bottom type to relate to the data on distribution, substrate was likely to be of secondary importance. There are no major substrate formations that are peculiar to the eastern Scotian Shelf where snow crab were most abundant. Emerald and La Have Basins are areas of mud deposition; these areas were presumably not habited by snow crab because of their relatively high bottom temperatures (Fig. 3).

Physiological studies of snow crab provide a basis to explain their preference to cold water. At temperatures above $7^{\circ} \mathrm{C}$ metabolic costs overtake inputs (Foyle et al., 1989), while at $13-15^{\circ} \mathrm{C}$ mortality begins (McLeese and Watson, 1968). This would suggest that snow crab found above $7^{\circ} \mathrm{C}$ are nonviable in the long-term. In the present surveys, the $7^{\circ} \mathrm{C}$ isotherm did appear to be an important boundary. Of 87 sets with snow crab from 1980-94, only 5 sets were from bottom temperatures of $7^{\circ} \mathrm{C}$ or greater. Of these five sets, 4 had 1-2 snow crab; one contained 31 (temperature was $9.6^{\circ} \mathrm{C}$ ). Possible explanations for the high number in the latter set were: (i) the snow crab were migrating, (ii) the 


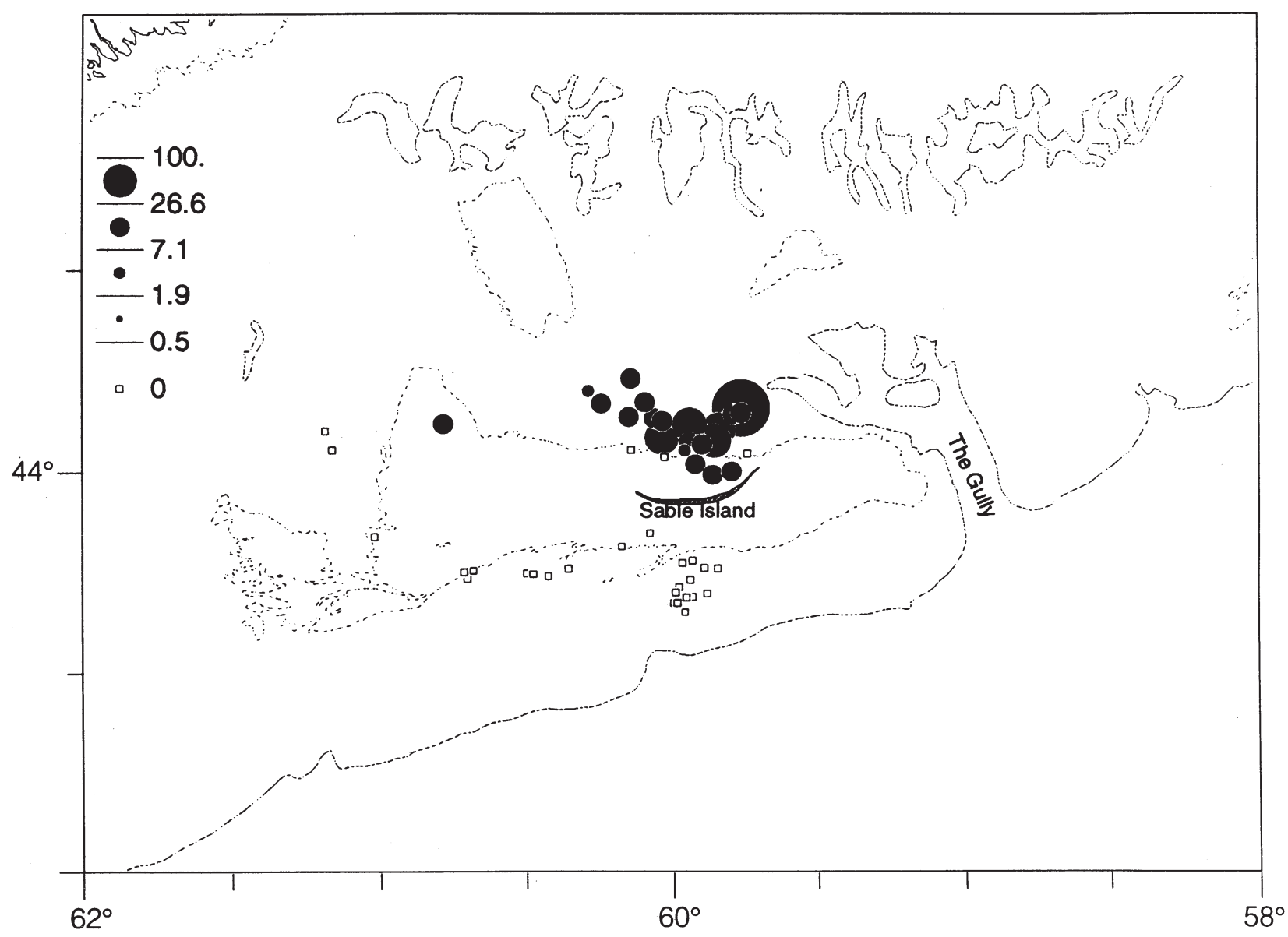

Fig. 8. Number of snow crab per set around Sable Island. Data obtained during a special groundfish survey directed at seal worm (17-19 May 1994).

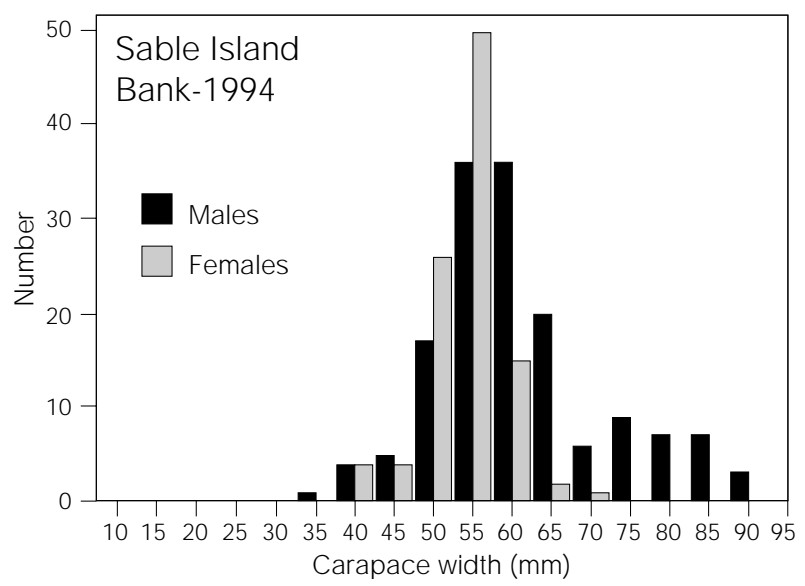

Fig. 9. Size distribution of snow crab collected around Sable Island.

measured bottom temperature did not reflect temperature experienced by snow crab due to withintow spatial variability.
Groundfish surveys indicate that the snow crab fishery was exploiting most of the areas where they were abundant on the Scotian Shelf. On the eastern Scotian Shelf areas of light or no exploitation include (i) north of Sable Island, (ii) a band of about 20 miles along the edge of the Laurentian Channel, and (iii) the eastern part of Banquereau Bank. With the exception of the area just north of Sable Island, snow crab catches during groundfish surveys in these areas were infrequent (Fig. 5 and 6).

West of the major fishing grounds, snow crab were rarely found in groundfish surveys and catch rates by the experimental fishery $(1.5 \mathrm{~kg} / \mathrm{trap}$ haul) were less than $10 \%$ of those on the commercial grounds off eastern Cape Breton (mean of $21 \mathrm{~kg}$ / trap haul in 1994). The experimental fishery on the western Scotian Shelf caught snow crab where groundfish surveys did not, indicating the trawls were not reliable for estimating low densities. While commercial catch rates on the western Scotian Shelf may improve with fishing skill, the snow crab biomass there is likely ephemeral and limited to 
TABLE 5. Snow crab occurrence and bottom temperature during spring, summer and autumn groundfish sets. Spring includes the $4 \mathrm{VW}$ Cod series. Expected numbers were based on the assumption that snow crab occurrence would be proportional to sampling effort. (All = all sets; $w / S C=$ sets with snow crab; Exp = expected number of sets with snow crab). For chi-square test adjacent categories were combined (indicated by superscript) so that expected number was $>3$. ${ }^{*} \mathrm{p}<0.05 ;{ }^{* *} \mathrm{p}<0.005$.

\begin{tabular}{|c|c|c|c|c|c|c|c|c|c|}
\hline \multirow{2}{*}{$\begin{array}{l}\text { Temperature } \\
\left({ }^{\circ} \mathrm{C}\right)\end{array}$} & \multicolumn{3}{|c|}{ Spring } & \multicolumn{3}{|c|}{ Summer } & \multicolumn{3}{|c|}{ Autumn } \\
\hline & All & w/SC & $\operatorname{Exp}$ & All & w/SC & Exp & All & $w / S C$ & Exp \\
\hline$<1$ & 241 & 3 & $2.8^{a}$ & 119 & 5 & $2.5^{\mathrm{a}}$ & 3 & 0 & $0.1^{\mathrm{a}}$ \\
\hline $1-2$ & 191 & 3 & $2.2^{a}$ & 197 & 17 & $4.1^{\mathrm{a}}$ & 33 & 3 & $0.9^{a}$ \\
\hline $2-3$ & 161 & 4 & $1.9^{b}$ & 253 & 8 & 5.2 & 57 & 2 & $1.5^{\mathrm{a}}$ \\
\hline $3-5$ & 225 & 4 & $2.6^{b}$ & 439 & 10 & 9.1 & 132 & 2 & $3.6^{a}$ \\
\hline $5-7$ & 170 & 1 & $2.0^{\mathrm{C}}$ & 543 & 9 & 11.3 & 171 & $1 \overline{1}$ & 4.6 \\
\hline $7-9$ & 207 & 0 & $1.8^{\mathrm{c}}$ & 621 & 2 & 12.9 & 158 & 1 & 4.3 \\
\hline $9-11$ & 79 & 0 & $0.8^{\mathrm{c}}$ & 302 & 1 & $6.3^{b}$ & 125 & 1 & $3.4^{b}$ \\
\hline $11-13$ & 11 & 0 & $0.2^{\mathrm{c}}$ & 27 & 0 & $0.6^{b}$ & 48 & 0 & $1.3^{b}$ \\
\hline $13-15$ & 0 & 0 & $0.1^{\mathrm{c}}$ & 6 & 0 & $0.1^{b}$ & 11 & 0 & $0.3^{b}$ \\
\hline $15-17$ & 0 & 0 & 0.0 & 0 & 0 & 0.0 & 4 & 0 & $0.1^{b}$ \\
\hline $\begin{array}{l}\text { Total } \\
\text { d. f. } \\
\text { Chi square }\end{array}$ & 1285 & 15 & $\begin{array}{c}15 \\
1 \\
6.5 \text { * }\end{array}$ & 2507 & 52 & $\begin{array}{c}52 \\
4 \\
57.8^{* *}\end{array}$ & 742 & 20 & $\begin{array}{c}20 \\
2 \\
14.8 \text { ** }\end{array}$ \\
\hline
\end{tabular}

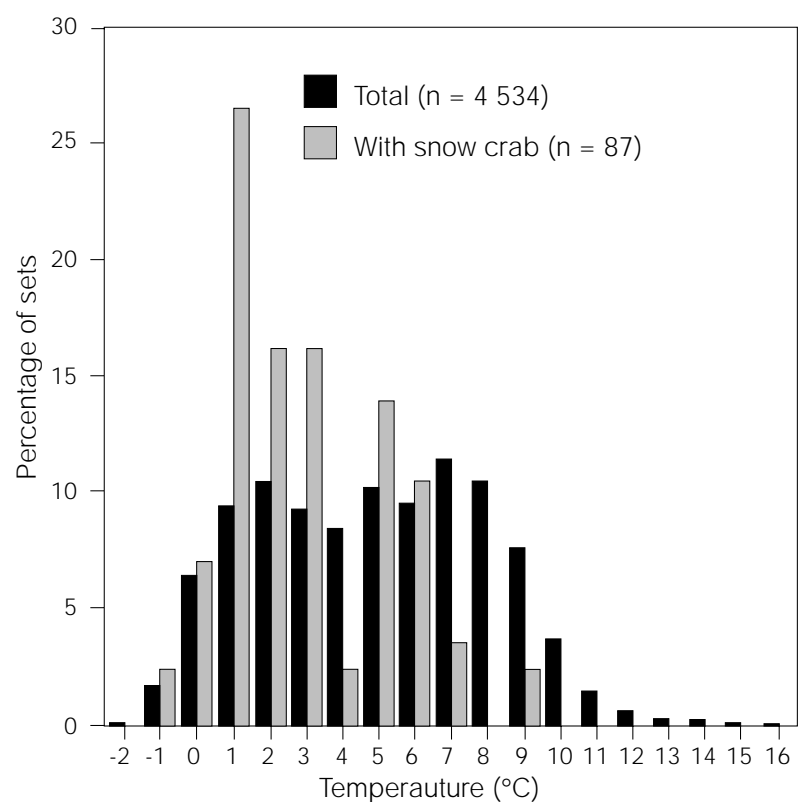

Fig. 10. Bottom temperature during all groundfish sets versus sets with snow crab. Georges Bank survey was excluded because no snow crab were found. See Table 5 .

pockets of cold bottom water along the coast and in the area southwest of La Have Basin (Fig. 3). These areas may support small fisheries during periods when recruitment has been favourable and when snow crab prices are high.

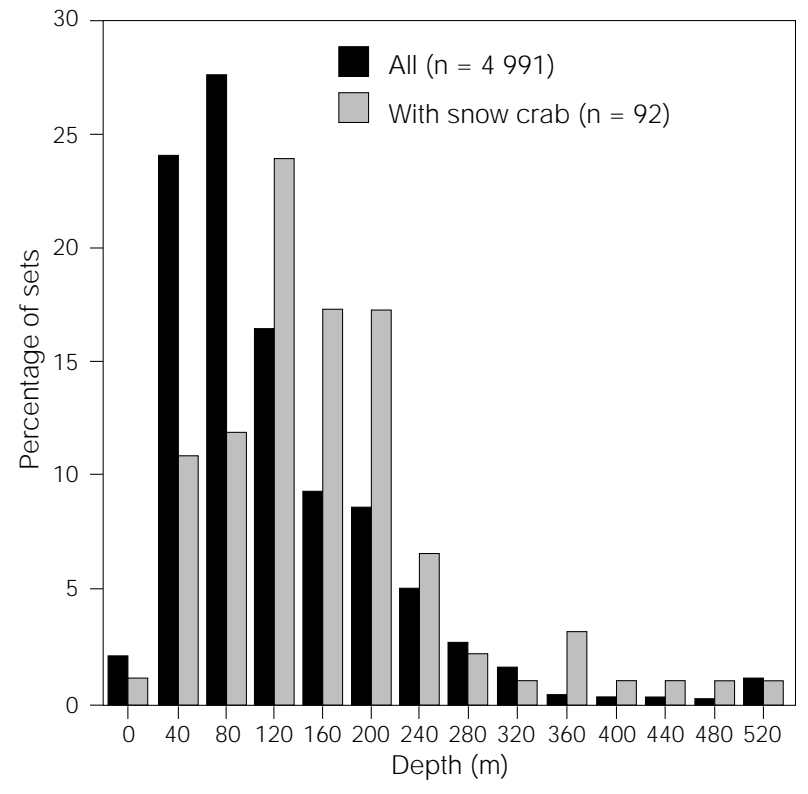

Fig. 11. Bottom depth during all groundfish sets versus sets with snow crab. See Table 6.

There are no records of any fishing for snow crab in the area just north of Sable Island, and those collected there by trawl in May 1994 were all less than the minimum legal size of $95 \mathrm{~mm}$ carapace width (Fig. 9). Possible explanations for the size distribution include gear selectivity, irregular recruitment and movement. Compared to traps, 
TABLE 6. Snow crab occurrence and bottom depth during spring, summer and autumn groundfish sets. Spring includes the $4 \mathrm{VW}$ Cod series. Expected numbers were based on the assumption that snow crab occurrence would be proportional to sampling effort. (All = all sets; $w / S C=$ sets with snow crab; Exp = expected number of sets with snow crab). For chi-square test adjacent categories were combined (indicated by superscript) so that expected number was $>3$. ${ }^{*} p<0.05 ;{ }^{* *} p<0.005$.

\begin{tabular}{|c|c|c|c|c|c|c|c|c|c|}
\hline \multirow{2}{*}{$\begin{array}{c}\text { Depth } \\
(\mathrm{m})\end{array}$} & \multicolumn{3}{|c|}{ Spring } & \multicolumn{3}{|c|}{ Summer } & \multicolumn{3}{|c|}{ Autumn } \\
\hline & All & $w / S C$ & Exp & All & w/SC & Exp & All & $w / S C$ & Exp \\
\hline $0-40$ & 29 & 0 & $0.3^{a}$ & 55 & 1 & $1.1^{\mathrm{a}}$ & 17 & 0 & $0.4^{\mathrm{a}}$ \\
\hline $40-80$ & 366 & 1 & $4.2^{a}$ & 654 & 8 & $13.4^{a}$ & 180 & 1 & $4.2^{a}$ \\
\hline $80-120$ & 398 & 2 & 4.5 & 753 & 6 & 15.4 & 230 & 3 & 5.4 \\
\hline $120-160$ & 250 & 5 & 2.8 & 416 & 13 & 8.5 & 153 & 4 & 3.6 \\
\hline $160-200$ & 130 & 4 & $1.5^{b}$ & 234 & 8 & 4.8 & 100 & 4 & $2.3^{\mathrm{b}}$ \\
\hline $200-240$ & 111 & 4 & $1.3^{b}$ & 226 & 9 & 4.6 & 88 & 3 & $2.1^{\mathrm{b}}$ \\
\hline $240-280$ & 64 & 0 & $0.7^{b}$ & 133 & 3 & $2.7^{b}$ & 55 & 3 & $1.3^{\mathrm{c}}$ \\
\hline 280-320 & 26 & 0 & $0.3^{b}$ & 68 & 2 & $1.4^{b}$ & 35 & 0 & $0.8^{\mathrm{c}}$ \\
\hline $320-360$ & 13 & 0 & $0.1^{b}$ & 46 & 1 & $0.9^{b}$ & 25 & 0 & $0.6^{\mathrm{c}}$ \\
\hline $360-400$ & 4 & 0 & $0.0^{b}$ & 11 & 2 & $0.2^{b}$ & 11 & 1 & $0.3^{c}$ \\
\hline $400-440$ & 12 & 0 & $0.1^{b}$ & 0 & 0 & 0.0 & 8 & 1 & $0.2^{c}$ \\
\hline $440-480$ & 4 & 0 & 0.0 & 0 & 0 & 0.0 & 11 & 1 & $0.3^{\mathrm{c}}$ \\
\hline $480-520$ & 1 & 0 & 0.0 & 0 & 0 & 0.0 & 12 & 1 & $0.3^{\mathrm{c}}$ \\
\hline$>520$ & & 0 & & & & & 62 & 1 & $1.4^{\circ}$ \\
\hline $\begin{array}{c}\text { Total } \\
\text { d. f. }\end{array}$ & 1408 & 16 & $\begin{array}{r}16 \\
2\end{array}$ & 2596 & 53 & $\begin{array}{r}53 \\
4\end{array}$ & 987 & 23 & $\begin{array}{r}23 \\
3\end{array}$ \\
\hline Chi square & & & 9.3 * & & & $17.9^{* *}$ & & & 7.1 \\
\hline
\end{tabular}

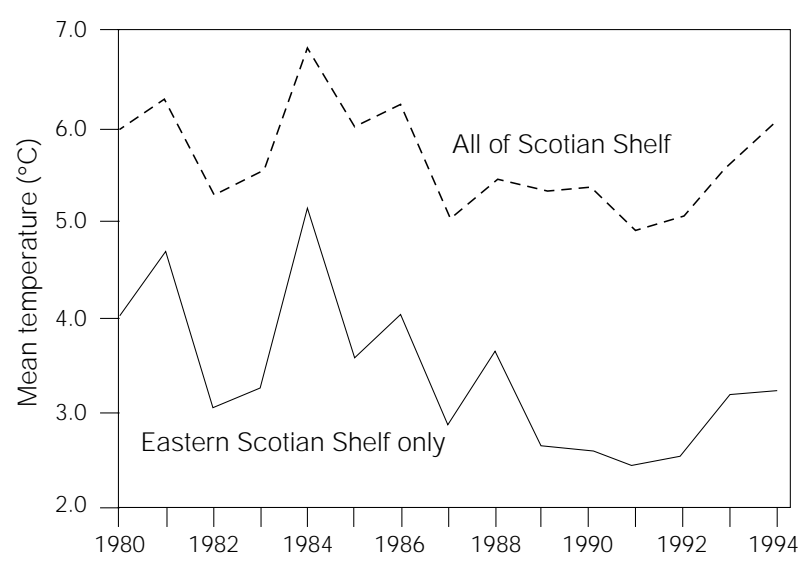

Fig. 12. Mean stratified bottom temperature in summer. Entire Scotian Shelf includes area shown in Fig. 6 ; eastern Scotian Shelf is approximately the area east of $61.5^{\circ}$ longitude (groundfish survey strata 440-459).

trawls can be less effective at capturing large crabs, but if present, some large crabs would be expected even in trawls (Hoenig and Dawe, MS 1991). It is possible that the snow crab north of Sable Island in 1994 resulted from an episodic recruitment event, and that these crab had not yet grown to commercial size. Although they were found north of Sable Island during each of the periods depicted in Fig. 6, size data are not available to evaluate how regularly recruitment occurs in this location. Another explanation for the lack of large animals is movement of snow crab from the area as they approach legal size. If this is the case, the area north of Sable Island may supplement the snow crab on the adjacent exploited grounds.

\section{Changes in production}

The increased landings from 1988 to 1994 were due largely to increased abundance of snow crab. Key to understanding the basis of the increase is the age of snow crab when they recruit to the fishery, and the age at which year-class size is determined. The first wave of recruits was detected in 1985 at a modal size of $57 \mathrm{~mm}$ (Elner and Robichaud, MS 1987). Based on Robichaud et al. (1989) these crab were 3-4 years old at the time, but recent studies (Sainte-Marie et al., 1995) indicate they were more likely to be approximately 6 years old (settled in 1979) in 1985. If taken in the soft-shelled condition, these crab would have recruited to the fishery in 1988. If they were retained by the fishery only if they were hard-shelled, the 1979 year-class would not have recruited until 1989, and thus would have been 9 years old. If skip-molting occurred, their entry into the fishery would have been further delayed. Thus 
the year-classes supporting the fishery from 1988 to 1994 would appear to have settled to the bottom from 1979-86 or earlier.

While it is generally assumed that events or conditions around the time of settlement are most critical to recruitment success in marine decapods (e.g. Cobb and Wahle 1994, Sainte-Marie et al., 1996), the survival and growth of later stages may also be important (Jamieson, 1986; Taylor et al., 1994). Possible explanations for the decline and subsequent increase in snow crab production on the eastern Scotian Shelf between the late-1970s and the mid-1990s fall under three broad categories: endogenous density-dependent processes, changes in the physical environment, and effects of reductions in groundfish.

\section{Density-dependent processes}

One density-dependent hypothesis suggests a fishing-induced shift in age structure with consequent effects on growth and survival rates, as proposed for snow crab in the southern Gulf of St. Lawrence (Elner and Bailey, 1986). According to this hypothesis there was a large biomass of older, slow-growing snow crabs off eastern Cape Breton at the start of exploitation, and they had accumulated over time and many were in terminal molt. Thus, the high virgin biomass resulted in high initial catch rates that sustained the fishery for about 3 years, and the subsequent year-classes were small resulting in decreased landings and catch rates. This hypothesis assumes interaction between older crab and newly settled crab and that removal of the older crabs allowed increased survivorship of younger, rapidly growing crabs, which entered the fishery in the late-1980s. In the northern Gulf of Saint Lawrence 1-2 year old snow crab are spatially segregated from older crab (Brêthes et al., 1987; Sainte-Marie et al., 1996), and thus older crab would generally not interact with newly settled individuals. If year-class size is determined around settlement time, and if newly settled crab are spatially segregated from older crab on the eastern Scotian Shelf, the hypothesis based on a fishery-induced shift in age structure cannot explain the increase in snow crab production off eastern Cape Breton in the late-1980s and 1990s.

Another density-dependent hypothesis suggests that the catch rates off eastern Cape Breton were initially high because the start of the fishery coincided with a period of high recruitment to fishable sizes (rather than because virgin biomass had been built up over time). This hypothesis, posed for snow crab in the northern Gulf of St. Lawrence (Sainte-Marie et al., 1996), suggests snow crab populations cycle independent of fishing, due to density dependence shortly after settlement.
Density-dependent feedback is hypothesized to occur due to space and food limitations, and cannibalism on newly-settled crab by slightly older individuals. This hypothesis predicts a 7-10 year cycle in recruitment. If it is to hold for eastern Cape Breton, the decline in biomass in the mid-1980s should have occurred even in the absence of the fishery, and a trough in recruitment to the fishery should be expected 7-10 years after the trough in 1985. Assuming 9 years between settlement and recruitment to the fishery, the year-classes comprising the high catches in the late-1970s and early-1980s would have originated in the late-1960s and early-1970s. The small year-classes comprising the fishery from 1982 to 1986 presumably originated from about 1973-77, before the fishery began. This suggests that a decline in biomass could have occurred even in the absence of a fishery.

Interpretation of the recruitment trend off eastern Cape Breton is complicated by the expansion in the fishing grounds, but there is some support for a recruitment trough beginning after 1992. Considering only Areas 21-22 (where the expansion in fishing grounds has been more limited than Areas 23-24), catch rates in 1994-95 (7-13 $\mathrm{kg} /$ trap haul) were down substantially from the peak of 1991-92 (25-30 kg/trap haul), but were still about double the catch rates of the mid-1980s (3-6 kg/ trap haul) (Tremblay and Eagles, 1996).

\section{Changes in the physical environment}

The physical environment must be especially important to recruitment and growth of snow crab on the Scotian Shelf, where the species is near its southern limit. Changes in abundance may result from changes in the retention or survival of planktonic larvae and early juvenile stages, due to variation in large-scale environmental features such as temperature or currents. The study of larval distribution on the Scotian Shelf in 1977-78 suggested dispersal from northeast to southwest (Roff et al., 1986). Given that late-stage larvae must have been sufficiently abundant from 1980-82 to provide the high levels of recruitment to the fishery in the late-1980s and early-1990s, Roff et al., (1986) either underestimated late-stage larval abundance on the eastern Scotian Shelf, or 1977-78 were atypical of the subsequent years. It is possible that the recirculation features on the eastern Scotian Shelf (Loder et al., 1997; Sheng and Thompson, 1996) vary in strength from year to year, resulting in a variation in larval supply to the bottom.

Given that snow crab prefer temperatures less than $3^{\circ} \mathrm{C}$, and that the mean summer bottom temperature for the eastern Scotian Shelf was generally above $2.4^{\circ} \mathrm{C}$ (Fig. 12), decreased temperatures in the 1980 s may have contributed to 
increased growth or to an increase in the size of the area that supported snow crab. The apparent expansion in the grounds occupied (Fig. 6) supports the latter hypothesis. The cooling trend during summer surveys in the second half of the 1980s (Fig. 12 ) is representative of other seasons on the eastern Scotian Shelf (e.g. Misaine Bank, Drinkwater et al., 1996). If year-class size is determined around the time of settlement, any effect of the cooling trend on recruitment to the fishery from 1988-94 must be secondary, because the year-classes contributing to the fishery would have already been established by 1985 . The proposed positive effect of lower than average temperatures on the Scotian Shelf contrasts with the situation in some parts of Newfoundland, where bottom temperatures in spring are so low $\left(<0^{\circ} \mathrm{C}\right)$ that abnormally cold years may cause interruptions in growth (Taylor et al., 1994).

\section{Decline in groundfish}

Declines in groundfish during the 1980s may have reduced snow crab mortality due to predation. Cod abundance on the eastern Scotian Shelf declined in the 1980s (Fig. 13), as did cod in Sydney Bight (DFO, 1995). Cod are known snow crab predators but their possible effect on the overall survival of snow crabs is confounded by changes in diet with age, season, habitat and crab abundance (Waiwood and Elner, 1982; Robichaud et al., 1991). Other non-commercial species (e.g. skate) may be more important predators (Robichaud et al., 1991). Decreased predation by cod could not have caused increased survival of snow crab after settlement between 1979 and 1985, since cod abundance was still high from 1980-84 (Fig. 13). Cod stomachs of individuals $30-80 \mathrm{~cm}$ fork length fed mainly on snow crab from 6-44 mm carapace width (Robichaud et al., 1991), which corresponds to an age of 6 months to 4-5 years (Sainte-Marie et al., 1995).

The decline in groundfish and consequent reduction in fishing effort may have had a more direct effect on snow crab survival. Some industry observers suggest that fishing for groundfish results in high discard mortality of snow crab. Since fishing continued into the 1990s, and closures have been in place only since 1993, any effect of decreased discarding on recruitment of snow crab to the fishery must be secondary to other factors.

The changes in snow crab production on the eastern Scotian Shelf can be attributed to several factors but the relative importance of each is difficult to determine. There is some support for the hypothesis of an endogenous recruitment cycle in eastern Scotian Shelf, but more study of the interaction of different life history stages are needed for a full evaluation. It cannot be resolved whether

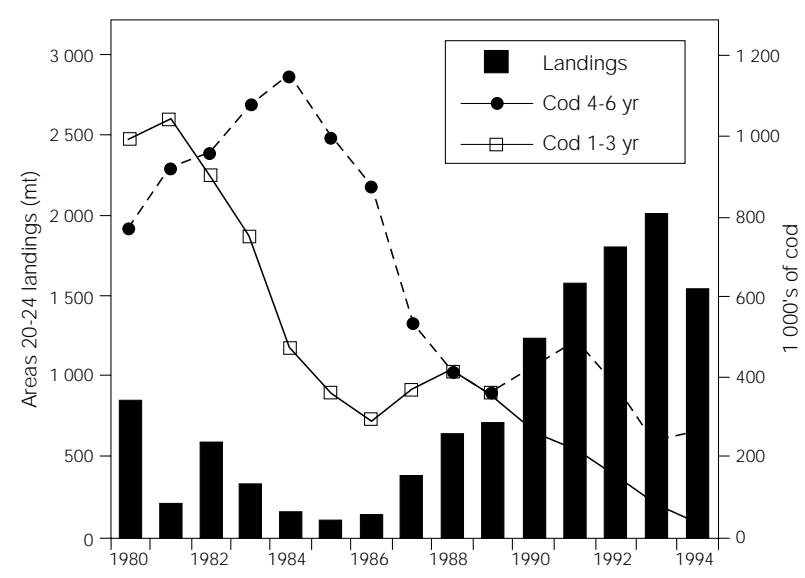

Fig. 13. Snow crab landings (Areas 20-24) and cod abundance on the eastern Scotian Shelf. Cod abundance estimates are from virtual population analysis in Fanning et al., MS 1995.

the high biomass at the beginning of the fishery resulted from a peak in a recruitment cycle, or from the accumulation of biomass by a population in a virgin state. The increased production in the late1980 s and early-1990s was due to successful yearclasses originating from about 1979-85. These yearclasses may have been larger because of increased survival of early life-history stages but the reasons for any increased survival are not clear. Densitydependent factors alone cannot explain the increased production in the late-1980s and early1990s. Lower temperatures after 1984 appear to have contributed to expanded habitat, and reduced predation from groundfish may have increased the survival and growth of juvenile and adolescent snow crab on the eastern Scotian Shelf.

\section{Acknowledgments}

I thank R. Branton and M. Strong for making the Marine Fish Division groundfish survey database available; J. Loder and G. Black for providing the Scotian Shelf summer bottom temperature data; J. Martell and G. MacLellan for collecting data on snow crab during their sealworm study; and M. Eagles for producing the maps of fishing effort distribution. R. Miller, M. Moriyasu, B. Sainte-Marie and E. Dawe are thanked for their comments on earlier versions of the manuscript.

\section{References}

BRÊTHES, J.-C., F. COULOMBE, P.-E. LAFLEUR, and R. BOUCHARD. 1987. Habitat and spatial distribution of early benthic stages of the snow crab Chionoecetes opilio O. Fabricus off the north shore of the Gulf of St. Lawrence. J. Crust. Biol., 7: $667-681$.

CARROTHERS, P. J. G. 1988. Scotia-Fundy groundfish 
survey trawls. Can. Tech. Rep. Fish. Aquat. Sci., 1609: iv $+27 p$.

COBB, J. S., and R. A. WAHLE. 1994. Early life history and recruitment processes of clawed lobsters. Crustaceana, 67: 1-25.

DAVIDSON, K., J. C. ROFF, and R. W. ELNER. 1985. Morphological, electrophoretic and fecundity characteristics of Atlantic snow crab, Chionoecetes opilio, and implications for fisheries management. Can. J. Fish. Aquat. Sci., 42: 474-482.

DFO (Department of Fisheries and Oceans) Sciences Branch. 1995. Scotia-Fundy Spring 1995 groundfish stock status report. DFO Atl. Fish. Stock Status Rep., No. 6, p.

DRINKWATER, K. F., E. COLBOURNE, and D. GILBERT. 1996. Overview of environmental conditions in the Northwest Atlantic in 1994. NAFO Sci. Coun. Studies, 25: 25-58.

DUFOUR, R. 1988. Overview of the distribution and movement of snow crab (Chionoecetes opilio) in Atlantic Canada. In: Proceedings of the International Workshop on Snow Crab Biology, December 8-10, 1987, Montreal, Quebec. G. S. Jamieson, and W. D. McKone (eds.) Can. MS. Rep. Fish. Aquat. Sci., 2005: 75-82.

ELNER, R. W. 1982a. Overview of the snow crab Chionoecetes opilio fishery in Atlantic Canada. In: Proceedings of the international symposium on the genus Chionoecetes. Lowell Wakefield Fisheries Symposia Series. University of Alaska. Alaska Sea Grant Report, No. 82-10: 5-18.

$1982 b$. Characteristics of the snow crab Chionoecetes opilio fishery off Cape Breton Island. In: Proceedings of the international symposium on the genus Chionoecetes. Lowell Wakefield Fisheries Symposia Series. University of Alaska. Alaska Sea Grant Report, No. 82-10: 657-680.

1988. Stock definition and larval mixing in the snow crab (Chionoecetes opilio). In: Proceedings of the International Workshop on Snow Crab Biology, December 8-10, 1987, Montreal, Quebec. G. S. Jamieson, and W. D. McKone (eds.). Can. MS. Rep. Fish. Aquat. Sci., 2005: 33-44.

ELNER, R. W., and R. F. J. BAILEY. 1986. Differential susceptibility of Atlantic snow crab, Chionoecetes opilio, stocks to management. Can. Spec. Publ. Fish. Aquat. Sci., 92: 335-346.

ELNER, R. W., and D. A. ROBICHAUD. MS 1987. Assessment of the 1986 fishery for snow crab, Chionoecetes opilio, off the Atlantic coast of Cape Breton Island. CAFSAC Res. Doc., No. 86, $35 \mathrm{p}$.

ELNER, R. W., R. E. SEMPLE, and M. GILLIS. MS 1990. The 1989 assessment for snow crab on the Atlantic coast of Cape Breton Island. CAFSAC Res. Doc., No. 9, $44 \mathrm{p}$.

ENNIS, G. P., R. G. HOOPER, and D. M. TAYLOR. 1990. Changes in the composition of snow crab (Chionoecetes opilio) participating in the annual breeding migration in Bonne Bay, Newfoundland. Can. J. Fish. Aquat. Sci., 47: 2242-2249.

FADER, G. B. J. 1991. Surficial geology and physical properties 5: surficial geology. In: East Coast Basin Atlas Series: Scotian Shelf; Atlantic Geoscience Centre, Geological Survey of Canada, p. 119.

FANNING, L. P., R. K. MOHN, and W. J. MACEACHERN. MS 1995. Assessment of $4 \mathrm{VsW}$ cod in 1994 with consideration of ecological indicators of stock status.
DFO Atl. Fish. Res. Doc., No. 73, 29 p.

FOYLE, T. P, R. K. O'DOR, and R. W. ELNER. 1989. Energetically defining the thermal limits of the snow crab. J. Exp. Biol., 145: 371-393.

HACHEY, H. B. 1942. The waters of the Scotian Shelf. J. Fish. Res. Board. Can., 5: 377-397.

HALLIDAY, R. G., and P. A. KOELLER. 1981. A history of Canadian groundfish trawling surveys and data usage in ICNAF Divisions 4TVWX. In: Bottom trawl surveys. W. G. Doubleday and D. Rivard (eds). Can. Spec. Publ. Fish. Aquat. Sci., 58: 27-41.

HOENIG, J. M., and E. G. DAWE. MS 1991. Relative selectivity of four sampling methods using traps and trawls for male snow crabs (Chionoecetes opilio). CAFSAC Res. Doc., No. 32, 18 p.

HOOPER, R. G. 1986. A spring breeding migration of the snow crab Chionoecetes opilio (O. Fabr.), into shallow water in Newfoundland. Crustaceana, 50: 257-264.

HOUGHTON, R. W., P. C. SMITH, and R. O. FOURNIER. 1978. A simple model for cross-shelf mixing on the Scotian Shelf. J. Fish. Res. Board Can., 35: 414-421.

JAMIESON, G. S. 1986. Implications of fluctuations in recruitment of selected crab populations. Can. J. Fish. Aquat. Sci., 43: 2085-2098.

KOELLER, P. A. 1991. Approaches to improving groundfish survey abundance estimates by controlling the variability of survey gear geometry and performance. J. Northw. Atl. Fish. Sci., 11: 51-58.

LANTEIGNE, M. MS 1985. Distribution spatio-temporelle des larves de crabe appartenant aux genres Chionoecetes et Hyas, dans la baie des Chaleurs, Canada. M.Sc. thesis, Université de Moncton, Moncton, N.B.

LEFEBVRE, L., AND J.-C. BRÊTHES. 1991. Orientation des déplacements de crabes de neiges mâles (Chionoecetes opilio), marqués dans le sud-ouest du golfe du Saint-Laurent. Can. J. Fish. Aquat. Sci., 48: 1167-1175.

LODER, J. W., G. HAN, C. G. HANNAH, D. A. GREENBERG, and P. C. SMITH. 1997. Hydrography and baroclinic circulation in the Scotian Shelf region: winter vs summer. Can. J. Fish. Aquat. Sci., 54(Suppl. 1 ), (in press).

LOVRICH, G. A., B. SAINTE-MARIE, and B. D. SMITH. 1995. Depth distribution and seasonal movements of Chionoecetes opilio (Brachyura: Majidae) in Baie Sainte-Marguerite, Gulf of Saint Lawrence. Can. J. Zool., 73: 1712-1726.

MCLEESE, D. W., AND J. WATSON. 1968. Oxygen consumption of the spider crab (Chionoecetes opilio) and the American lobster (Homarus americanus) at a low temperature. J. Fish. Res. Board Can., 25: 1729-1732.

MCLELLAN, H. J. 1954a. Bottom temperatures on the Scotian Shelf. J. Fish. Res. Board Can., 11: 404-418.

1954b. Temperature-salinity relations and mixing on the Scotian Shelf. J. Fish. Res. Board Can., 11: 419-430.

MILLER, R. J. 1975. Density of the commercial spider crab, Chionoecetes opilio, and calibration of effective area fished per trap using bottom photography. J. Fish. Res. Board Can., 32: 761-768.

OSTLE, B., and R. W. MENSING. 1975. Statistics in research. lowa State University Press. Ames, lowa.

PIPER, D. J. W. 1991. Seabed geology of the Canadian eastern continental shelf. Continental Shelf Res., 11: 1013-1035. 
POWLES, H. 1968. Distribution and biology of the spider crab Chionoecetes opilio in the Magdalen Shallows, Gulf of St. Lawrence. Fish. Res. Board Can. MS Rep., No. 997, 105 p.

RATHBUN, M. J. 1929. Canadian Atlantic Fauna 10. Arthropoda. $10 \mathrm{~m}$. Decapoda. Biological Board of Canada, Atlantic Biological Station. St. Andrews, N.B.

ROBICHAUD, D. A., R. F. J. BAILEY, and R. W. ELNER. 1989. Growth and distribution of snow crab, Chionoecetes opilio, in the southeastern Gulf of St. Lawrence. J. Shellfish Res., 8: 13-23.

ROBICHAUD, D. A., R. W. ELNER, and F. J. BAILEY. 1991. Differential selection of crab Chionoecetes opilio and Hyas sp. as prey by sympatric cod Gadus morhua and thorny skate Raja radiata. Fish. Bull., 89: 669680.

ROFF, J. C., L. P. FANNING, and A. B. STASKO. 1986. Distribution of larval crabs (Decapoda: Brachyura) on the Scotian Shelf. Can. J. Fish. Aquat. Sci., 43: 587-599.

SAINTE-MARIE, B., and F. HAZEL. 1992. Moulting and mating of snow crabs, Chionoecetes opilio ( $O$. Fabricius), in shallow waters of the northwestern Gulf of Saint Lawrence. Can. J. Fish. Aquat. Sci., 49: 12821293.

SAINTE-MARIE, B., J.-M. SÊVIGNY, B. D. SMITH, and G. A. LOVRICH. 1996. Recruitment variability in snow crab Chionoecetes opilio: pattern, possible causes, and implications for fishery management. In: International Symposium on biology, management and economics of crabs from high latitude habitats. Lowell Wakefield Fisheries Symposium, (in press).

SAINTE-MARIE, B., S. RAYMOND, and J.-C. BRÊTHES. 1995. Growth and maturation of the benthic stages of male snow crab, Chionoecetes opilio (Brachyura: Majidae). Can. J. Fish. Aquat. Sci., 52: 903-924.

SHENG, J., and K. R. THOMPSON. 1996. A robust method for diagnosing regional shelf circulation from vertical density profiles. J. Geophys. Res. (submitted), 29 p. SMITH, P. C., B. PETRIE, and C. R. MANN. 1978. Circulation, variability and dynamics of the Scotian Shelf and Slope. J. Fish. Res. Board Can., 35: 10671083.

STEHLIK, L. I., C. L. MACKENZIE JR., and W. W. MORSE. 1991. Distribution and abundance of four brachyuran crabs on the Northwest Atlantic Shelf. Fish. Bull., 89: 473-492.

TAYLOR, D. M. 1988. A review of literature pertaining to the reproductive biology of the genus Chionoecetes. In: Proceedings of the International Workshop on Snow Crab Biology, December 8-10, 1987, Montreal, Quebec. G. S. Jamieson, and W. D. McKone (eds.) Can. MS. Rep. Fish. Aquat. Sci., 2005: 67-74.

TAYLOR, D. M., P. G. O'KEEFE, and C. FITZPATRICK. 1994. A snow crab Chionoecetes opilio (Decapoda, Majidae), fishery collapse in Newfoundland. Fish. Bull., 92: 412-419.

TREMBLAY, M. J., and M. D. EAGLES. MS 1995. Assessment of the 1994 snow crab fishery off eastern Cape Breton (Areas 20-24). DFO Atl. Fish. Res. Doc., No. 1, 29 p.

MS 1996. Assessment of the 1995 snow crab fishery off eastern Nova Scotia. DFO Atl. Fish. Res. Doc., No. 35, 29 p.

TREMBLAY, M. J., M. D. EAGLES, and R. W. ELNER. 1994. Catch, effort and population structure in the snow crab fishery off eastern Cape Breton, 1978-1993: a retrospective. Can. Tech. Rep. Fish. Aquat. Sci., 2021: $47 \mathrm{p}$.

WAIWOOD, K. G., and R. W. ELNER. 1982. Cod predation of snow crab (Chionoecetes opilio) in the Gulf of St. Lawrence. In: Proceedings of the international symposium on the genus Chionoecetes. Lowell Wakefield Fisheries Symposia Series. University of Alaska. Alaska Sea Grant Report, No. 82-10: 499-502. 